\title{
含歯性票胞と原始性衰胞の臨床的・病理組織学的検討
}

\author{
中 村誠司・篠原正徳・原田猛 \\ 廣木朗子・岡 増一郎
}

\section{Clinical and histological study of dentigerous and primordial cysts}

\author{
Seiji Nakamura $\cdot$ Masanori Shinohara $\cdot$ Takeshi Harada \\ Akiko Hirokı $\cdot$ Masuichiro OKA
}

\begin{abstract}
Sixty dentigerous and 10 primordial cysts were examined clinically and pathologically. Fifty-six of the dentigerous cysts had non-keratinizing epithelium and 9 of the dentigerous cysts had keratinizing epithelium. However, 5 keratinizing dentigerous cysts and 1 non-keratinizing primordial cyst were observed as exceptions.

Radiographically, the dentigerous cysts were generally of unilocular round shape with a well-defined border. However, the well-defined border was often lost due to severe infection. In contrast, the primordial cysts were more frequently shown to be of irregular and multilocular shape, and the well-defined border was well preserved even with severe infection. Thus, keratinizing epithelium was suggested to be involved in the formation of irregular and multilocular shape and to be more resistant to infection.

Pathologically, non-keratinizing epithelium often showed proliferation, a lacy appearance, and ridge elongation in association with inflammatory cell infiltration. In contrast, such changes in keratinizing epithelium were rarely observed even with heavy inflammation. Interestingly, ameloblastoma-like epithelial proliferation and calcification in the absence of inflammation were partially observed in 6 and 7 cases, respectively, independent of keratinization of epithelium. Thus, odontogenic epithelial cells were suggested to have high proliferative and differentiative activities.
\end{abstract}

Key words: developmental odontogenic cyst (発育性歯原性衰胞), dentigerous cyst (含歯性衰胞), primordial cyst (原始性衰輣胞), odontogenic keratocyst (歯原性角化裹胞), ameloblastoma (エナメル上皮腫)

\section{緒}

言

発育性歯原性囊胞は主に含歯性嚢胞 (dentigerous cyst）と原始性譲胞（primordial cyst）からなり，こ れらは濾胞性歯䡛胞として一括分類されることが多く, 前者は種々の程度に発育した埋伏歯を襄胞壁に有する もので, 後者は歯質を有していないものとされてい た ${ }^{1 \sim 4)}$. しかし, 1956 年にPhilipsen ${ }^{5)}$ が歯原性角化

九州大学歯学部口腔外科学第二講座

(主任 : 岡 增一郎教授)

Second Department of Oral and Maxillofacial

Surgery, Faculty of Dentistry, Kyushu University

(Chief: Prof. Masuichiro Oka)

受付日: 平成 6 年 5 月 16 口

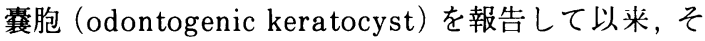
の位置付けや翼胞の分類に混乱を生じていたが, 現在 では 1992 年の WHO 分類 ${ }^{6)}$ のように歯原性角化䡛胞 は原始性輁胞と同一疾患とする見解が一般的となって いる7).

しかしながら，角化層を持たない原始性囊胞や角化 層をもつ含歯性襄胞が存在するという報告 8 -14) は従 来よりあり，歯原性角化襄胞と原始性襄胞とを全くの 同一疾患とする見解には疑問があるように思われる. また, 襄胞上皮の由来に関しても, 含歯性囊胞は退縮 エナメル上皮由来であると一般に認められているが， 原始性襄胞については歯堤上皮やその残遺物由来であ るとか, 口腔粘膜の基底細胞由来であるとか意見の統 一をみていない $3,14 \sim 16)$.このように, 含歯性囊胞と原 
始性襄胞の囊胞上皮の由来や性状についてさらに比較 検討し, 分類方法などについても再考する必要がある と思われる.そこで, 今回われわれは, 含歯性襄胞と 原始性囊胞について臨床的・病理組織学的に比較・検 討を加えたので報告する。

\section{対象と方 法}

対象は, 昭和 60 年から平成 4 年までの 8 年間に九州 大学歯学部第二口腔外科を受診し, 臨床的 - 病理組織 学的検索により含歯性襄胞あるいは原始性襄胞と診断 され，さらに十分な検索が可能であった 70 例であっ た.このうち含歯性䡛胞は 60 例, 原始性襄胞は 10 例 であった. 年齢は 6 歳から 80 歳までで, 平均 29.2 歳で あった. 性別は, 男性 43 例女性 27 例であった。

臨床的検討は, カルテから性, 年齢, 症状, 治療法, 予後などを調查し, 術前の X 線写真や術中所見から発 生部位, 歯との関係, 襄胞の形態および性状, 周囲の 性状および変化について検索した. 病理組織学的検討 は, 生検材料や切除あるいは摘出材料から作製した組 織標本を用いて行った.

なお, 含歯性囊胞と原始性嚢胞との鑑別診断は, 術 前の X 線写真や術中所見をもとに, 襄胞壁に埋伏歯を 含むものを含歯性囊胞, 襄胞壁に歯質を含まないもの を原始性囊胞とし, 診断の上では輁胞上皮の角化の有 無は考慮しなかった。病理組織学的に非角化襄胞と角 化襄胞とに分類すると, 非角化襄胞が 56 例, 角化囊胞 が14例であった。

\section{結果}

\section{1. 発生部位および頻度}

含歯性囊胞の発生部位は上顎が 23 例, 下顎が 37 例 であった。㤟胞腔内に含まれていた歯別に分けてみる と, 上顎の場合は正中過剩歯が 10 例と最も多く, 以下, 犬歯が 7 例, 小白歯が 3 例, 智歯が 2 例, 切歯が 1 例で あり, 下顎の場合は小自歯が 18 例, 智歯が 18 例とこ れらがほとんどを占め, 残りの 1 例は犬歯であった。

原始性襄胞の発生部位は上顎が 2 例, 下顎が 8 例で あった. 上顎の 2 例はともに前歯部で,下顎の場合は 下顎角部から下顎枝部にかけてが 5 例と多く, 他は臼 歯部が 2 例, 前歯部が 1 例であった.

\section{2. 賈胞の形態および性状}

$\mathrm{X}$ 線学的所見と手術時の肉眼的所見をもとに衰胞 の形態を検索すると, 含歯性襄胞は 60 例のうち 48 例 の $80 \%$ が類円形で, 54 例の $90 \%$ が単胞性であった. 不 整形のものや多胞形のものもみられたが, これらの多 くは角化霊胞であった。これに対し，原始性襄胞は 10 例のうち 5 例の $50 \%$ が不整形で, また，同じく 5 例の $50 \%$ が多胞形であり, いわゆる貝款状も 3 例でみられ
表 $1 \mathrm{X}$ 線学的な裹胞の形態と性状

\begin{tabular}{c|cc}
\hline & 類円形 & 不整形 \\
\hline 含㐘性裹胞 & $48(1)$ & $12(4)$ \\
原始性襄胞 & $5(4)$ & $5(5)$ \\
\hline \multicolumn{2}{|c}{$(\quad)$ は角化襄胞の症例数 }
\end{tabular}

表 $2 \mathrm{X}$ 線学的な裹胞の形態と性状

\begin{tabular}{c|cc}
\hline & 単胞性 & 多胞性 \\
\hline 含歯性襄胞 & $54(2)$ & $6(3)$ \\
原始性襄胞 & $5(4)$ & $5(5)$ \\
\hline \multicolumn{2}{|c}{ ( ) は角化襄胞の症例数 }
\end{tabular}

表 3 霊胞周囲の X 線学的骨硬化線の性状

\begin{tabular}{|c|c|c|c|}
\hline & 明瞭 & 一部不明瞭 & 不明瞭 \\
\hline 含歯性囊胞 & $28(3)$ & $22(2)$ & $10(0)$ \\
\hline 原始性襄胞 & $8(7)$ & $1(1)$ & $1(1)$ \\
\hline
\end{tabular}

\section{た(表 1 , 表 2 ).}

$\mathrm{X}$ 線学的所見と手術時の肉眼的所見をもとに多胞 性と判断した 11 例に加えて, 病理組織学的にいわゆ る娘䡛胞の存在が確認された症例が 4 例あった。これ らを含めた 15 例のうち，9例が含歯性棗胞， 6 例が原 始性囊胞であった. 原始性囊胞は半数以上という高い 頻度で多胞性であった。 また, その 15 例には角化囊胞 が 10 例含まれており, 角化囊胞は 14 例のうち 10 例が 多胞性であった。

\section{3. 兾胞周囲の性状および変化}

骨の膨隆や皮質骨の消失および菲薄化などの襄胞の 増大に伴う周囲の骨の変化を検索したところ, 含画性

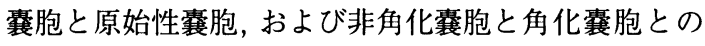
間にはそれらの出現頻度には差はみられなかった。ま た, 歯槽硬線の消失, 歯根の吸収, 失活などの隣接歯 への影響も検索したが, それらの出現頻度にも差はみ られなかった。

囊胞周囲の X 線学的な骨硬化線の性状をみてみる と, 含歯性襄胞よりも原始性囊胞の方が, また非角化 囊胞よりも角化嚢胞の方がより骨硬化線が明瞭である 症例が多かった（表 3 ).

臨床的に炎症所見を認めるような症例の方が骨硬化 線が不明暸なことが多いと思われたので, 炎症の程度 と骨硬化線の性状との関係を全症例を通して検討した （表 4 ）。炎症の程度は，採取した輁胞壁における炎症 性細胞の浸潤程度で評価し, なし, 軽度, 中等度, 高度 の 4 段階に分けた. なお，急性炎症のために切開・排 
表 4 炎症の程度と骨硬化線の性状との関係

\begin{tabular}{|c|c|c|c|}
\hline \multirow[b]{2}{*}{ 炎症の程度 } & \multicolumn{3}{|c|}{ 骨硬化線の性状 } \\
\hline & 明 瞭 & 一部不明瞭 & 不明瞭 \\
\hline な L & 11 & 1 & 0 \\
\hline 軽 度 & 14 & 3 & 1 \\
\hline 中等度 & 8 & 5 & 3 \\
\hline 高 度 & 4 & 12 & 8 \\
\hline
\end{tabular}

表 5 䡛胞上皮の増生像

\begin{tabular}{c|rc}
\hline & 有 & 無 \\
\hline 含歯性囊胞 & $11(0)$ & $49(5)$ \\
原始性霊胞 & $2(2)$ & $8(7)$ \\
\hline
\end{tabular}

（）は角化嚢胞の症例数
表 6 襄胞上皮の上皮脚延長

\begin{tabular}{|c|c|c|}
\hline & 有 & 無 \\
\hline 含歯性襄胞 & $22(1)$ & $38(4)$ \\
\hline 原始性裏胞 & $1(1)$ & $9(8)$ \\
\hline
\end{tabular}

（）は角化裹胞の症例数

表 8 䡛胞上皮の一部にエナメル上皮腫様変化を呈した症例

\begin{tabular}{|c|c|c|c|c|c|c|c|c|c|c|}
\hline \multirow{2}{*}{ 症例 } & \multirow{2}{*}{ 診断名および部位 } & \multicolumn{3}{|c|}{$\mathrm{X}$ 線学的所見 } & \multicolumn{3}{|c|}{ 隣接歯牙への影響 } & \multicolumn{3}{|c|}{ 襄胞上皮の性状 } \\
\hline & & 形態 & 性状 & 骨硬化線 & 硬線消失 & 根吸収 & 失活 & 脚延長 & レース状 & 増生 \\
\hline 1 & 含歯性䡬胞, $\longdiv { 5 }$ & 類円 & 単胞 & \pm & - & - & - & + & + & + \\
\hline 2 & 含歯性䡛胞, $\longdiv { 5 }$ & 類円 & 単胞 & - & + & - & - & + & + & + \\
\hline 3 & 含歯性囊胞, 上顎正中過㮃歯 & 類円 & 単胞 & \pm & + & + & - & + & + & + \\
\hline 4 & 含歯性螹胞, $\longdiv { 8 }$ & 不整 & 多胞 & \pm & - & - & - & + & + & + \\
\hline 5 & $\begin{array}{l}\text { 含歯性襄胞, } 81 \\
\text { (角化嚢胞) }\end{array}$ & 類円 & 単胞 & \pm & + & + & + & + & + & - \\
\hline 6 & $\begin{array}{l}\text { 原始性䡛胞, 左下顎骨体部 } \\
\text { (角化囊胞) }\end{array}$ & 不整 & 多胞 & + & + & + & + & + & - & + \\
\hline
\end{tabular}

膿処置を施行した症例では, 消炎後に異胞壁および上 皮を採取することが多かったので, 臨床的に高度炎症 例と判断した。その結果, 含歯性囊胞と原始性囊胞, および非角化囊胞と角化囊胞との間には炎症を伴う頻 度には差はみられず, 炎症を伴わない症例では骨硬化 線は明瞭で, 炎症の程度が増すにつれて不明瞭になる 傾向を認めた。

\section{4. 璂胞上皮の性状および変化}

炎症を伴わない典型的な症例では, 非角化囊胞上皮 は $2 \sim 3$ 層の立方上皮からなるもの, 数層で一部円柱 上皮よりなるもの，十数層の上皮よりなるもの，さら に一部に錯角化が認められるものと多様であった。一 方，角化襄胞上皮は数層の細胞からなり，表層部に著 明な角化層が認められた（写真 $1 \sim 4)$. 炎症を伴う症
表 7 襄胞上皮のレース状変化

\begin{tabular}{c|cc}
\hline & 有 & 無 \\
\hline 含歯性襄胞 & $24(1)$ & $36(4)$ \\
原始性裹胞 & $0(0)$ & $10(9)$ \\
\hline \multicolumn{2}{|c}{ ( ) は角化裹胞の症例数 }
\end{tabular}


表 9 裹胞上皮あるいは壁の一部に石灰化を認めた症例

\begin{tabular}{|c|c|c|c|c|c|c|c|c|c|c|c|c|c|}
\hline \multirow{2}{*}{ 症例 } & \multirow{2}{*}{ 診断名および部位 } & \multicolumn{3}{|c|}{$\mathrm{X}$ 線学的所見 } & \multirow{2}{*}{\multicolumn{3}{|c|}{$\begin{array}{l}\text { 隣接歯牙への影響 } \\
\text { 硬線消失 根吸収 失活 }\end{array}$}} & \multirow{2}{*}{\multicolumn{3}{|c|}{$\begin{array}{l}\text { 襄胞上皮の性状 } \\
\text { 脚延長 } レ \text { - } \text { 状増生 }\end{array}$}} & \multirow{2}{*}{\multicolumn{2}{|c|}{$\begin{array}{l}\text { 石灰化の部位 } \\
\text { 上皮内 壁内 }\end{array}$}} & \multirow{2}{*}{$\begin{array}{c}\text { 歯原性 } \\
\text { 上皮 }\end{array}$} \\
\hline & & 形態 & 性状 & 骨硬化線 & & & & & & & & & \\
\hline 1 & 含歯性衰胞, $\overline{81}$ & 類円 & 単胞 & + & + & - & - & - & - & - & - & & - \\
\hline 2 & 含歯性裹胞, $\overline{81}$ & 類円 & 単胞 & + & - & - & - & - & - & - & - & + & - \\
\hline 3 & 含歯性粪胞, $\mid 3$ & 類円 & 単胞 & + & + & + & + & - & - & - & - & & ++ \\
\hline 4 & 含歯性衰脿, 3 | & 類円 & 単胞 & + & + & - & - & - & - & - & - & & ++ \\
\hline 5 & 含歯性粪胞, $\longdiv { 8 }$ & 不整 & 多胞 & \pm & - & - & - & + & + & + & + & & - \\
\hline 6 & 含歯性裹胞, $\longdiv { 5 }$ & 類円 & 単胞 & + & - & - & - & - & - & + & + & & - \\
\hline 7 & $\begin{array}{c}\text { 原始性衰胞, 上顎前菌部 } \\
\text { （角化襄胞） }\end{array}$ & 不整 & 単胞 & - & + & + & + & - & - & + & + & & - \\
\hline
\end{tabular}

わない上皮の増生, 上皮脚の延長, レース状変化といっ た裹胞上皮の変化で, エナメル上皮腫様の上皮增殖を

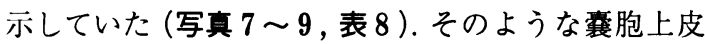
の変化は 6 例にみられたが, 霊胞の部位, 輁胞の種類, 角化の有無, 襄胞周囲の性状や変化などとの明らかな 関係はなかった.また,これら上皮の増殖は裹胞腔内 へ突出し増殖する場合と, 潩胞壁の方への增殖を示す 場合とがあった（写真 10,11）:

第二の興味ある所見は, 裹胞上皮あるいは裹胞壁の 石灰化であり，7例にみられた（表 9 )。この所見も， 襄胞の部位, 襄胞の種類, 角化の有無, 輁胞周囲の性 状や変化との明らかな関係はなかった. 強い炎症を伴 い, 襄胞壁内に石灰化を認めたものが 2 例，結合組織 に富んだ霊胞壁中に多くの歯原性上皮とともに石灰化 物を示したものが 2 例, エナメル上皮腫様の上皮の增 生に伴ったものが 3 例であった (写真 12,13 ).

\section{考察}

本研究では含歯性襄胞と原始性裹胞とに分類し，そ れらの囊胞上皮の角化について検討したが，原始性襄 胞は歯原性角化囊胞と同一のものとする現在の WHO の分類 ${ }^{6)}$ には必ずしも一致しなかった.

含歯性襄胞のなかに錯角化を認めたものが 4 例, 正 角化を認めたものが 1 例みられたが, いずれも下顎智 歯の歯冠を襄胞腔内に含んでいた。 過去に同じょうな 症例の報告 $8,9,13)$ があるが, それらの報告では埋伏歯 の歯頸部で退縮エナメル上皮と襄胞上皮が直接連絡し ているのを確認している.われわれの症例では確認で きなかったので, 臼後部に生じた原始性襄胞が拡大す るときに下顎智歯の歯冠を含んだ可能性も否定するこ とはできないが, 退縮エナメル上皮由来の角化性含歯
性䡛胞が存在する可能性は十分にあると思われる.

原始性襄胞のなかには角化を認めないものが 1 例含 まれていた。この囊胞は先天的に欠損していた下顎側 切歯に相当する下顎骨体部に存在し, 中切歯と犬歯の 根は離開していた。 下顎正中襄胞の可能性も完全には 否定できないが, 下顎側切歯の歯胚上皮に由来する非 角化性原始性囊胞が最も考えられた。同様の非角化性 原始性囊胞の報告14) もみられ, 下顎枝部や歯根部など のどの部位にも発生するとされている.

このように, 原始性䡛胞は歯原性角化襄胞と同一の ものとする現在のWHO の分類 ${ }^{6)}$ には問題があるよ うに思われる. 原始性襄胞のすべてが角化囊胞ではな いのは, 原始性襄胞の上皮が角化性である口腔粘膜の 基底細胞や硬組織形成前のエナメル器や歯堤上皮だけ ではなく, 非角化性である歯胚上皮やマラッセの上皮 遺残など種々のものからも発生することがあるからで あろう. また, 含歯性襄胞でも角化襄胞のことがある のは, 非角化性上皮である退縮エナメル上皮が角化性 上皮に変化することがあるからであろう. Pindborg ら ${ }^{15)}$ や Toller ${ }^{16)}$ は歯原性角化囊胞は原始性囊胞だけ でなく含歯性輁胞, 歯根囊胞, 残留囊胞をも含み, 非 特異的な組織学的名称として用いている. 歯の形成と 囊胞発生の時期をもとにした分類と, 囊胞上皮の組織 学的分類とを混同しない発育性襄胞上皮の分類方法を 考えるべきであろう.

発生頻度および部位については, 過去の報告 7,12,17, 18) と同様で, 含歯性襄胞のほうが原始性囊胞よりも発生 頻度が高く, 含歯性囊胞では下顎小臼歯, 下顎智歯, 上顎正中過剩歯を含むものが多く, 原始性裹胞では下 顎智歯部で下顎枝部へ広がるものが多かった。

形態および性状についても，過去の報告 $6,7,10,18,19)$ と同様に原始性襄胞の方が不整形, 多胞性である頻度 


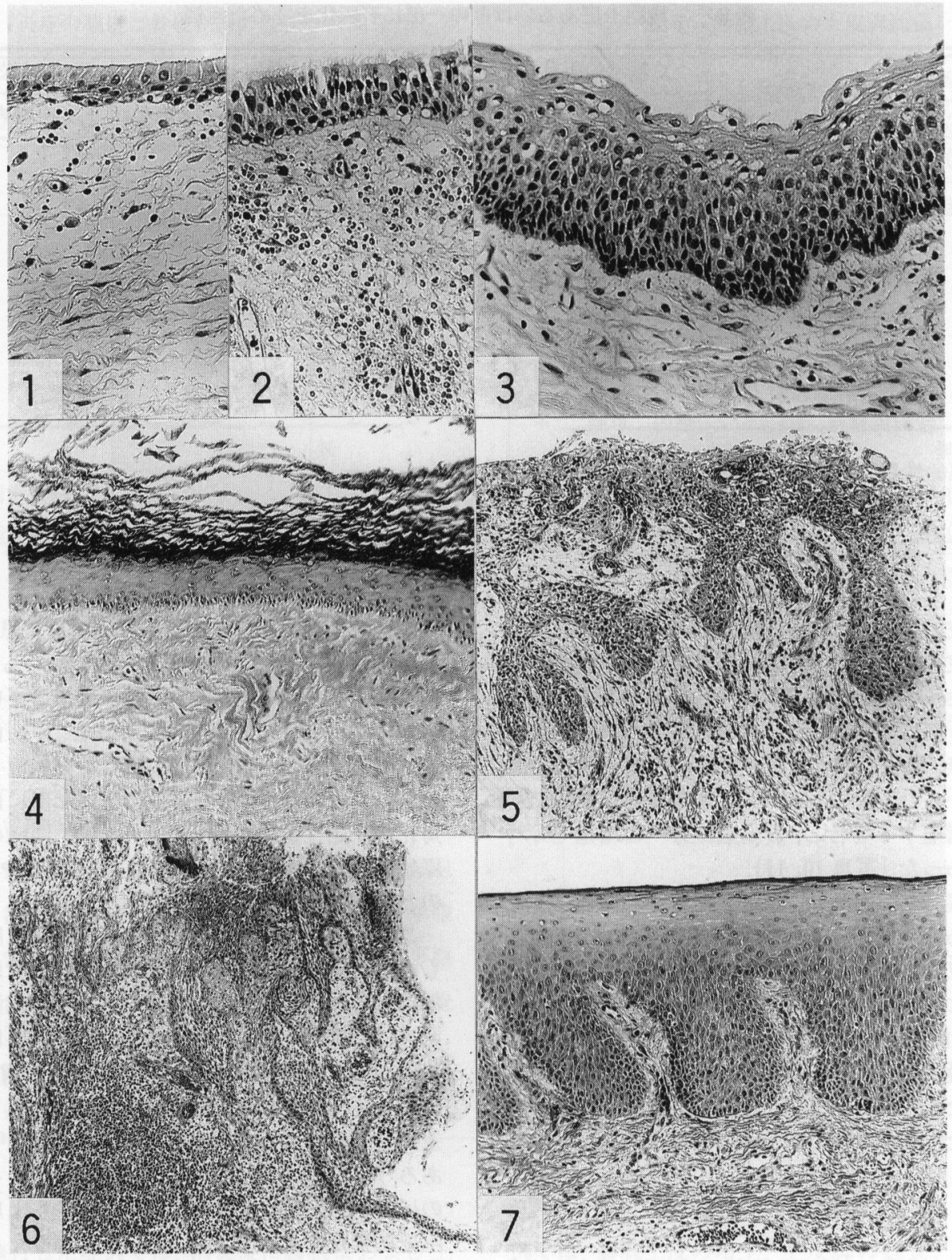

写真 1 非角化囊胞 $(\times 210) .2 \sim 3$ 層の立方上皮よりなる.

写真 2 非角化囊胞 $(\times 210)$. 数層で一部円柱上皮よりなる.

写真 3 非角化囊胞 $(\times 210)$. 多層の立方上皮よりなる

写真 4 角化囊胞 $(\times 105)$. 数層の上皮よりなり, 表層部には著明な角化層がみられる.

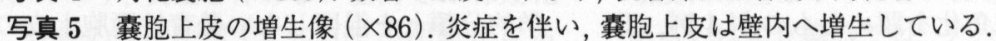

写真 6 囊胞上皮のレース状変化 $(\times 57)$. 著明な炎症を伴い, 輁胞上皮はレース状に増生している.

写真 7 炎症を伴わない衰胞上皮の増生像 $(\times 105)$. 上皮脚の塊状の増生がみられる。 

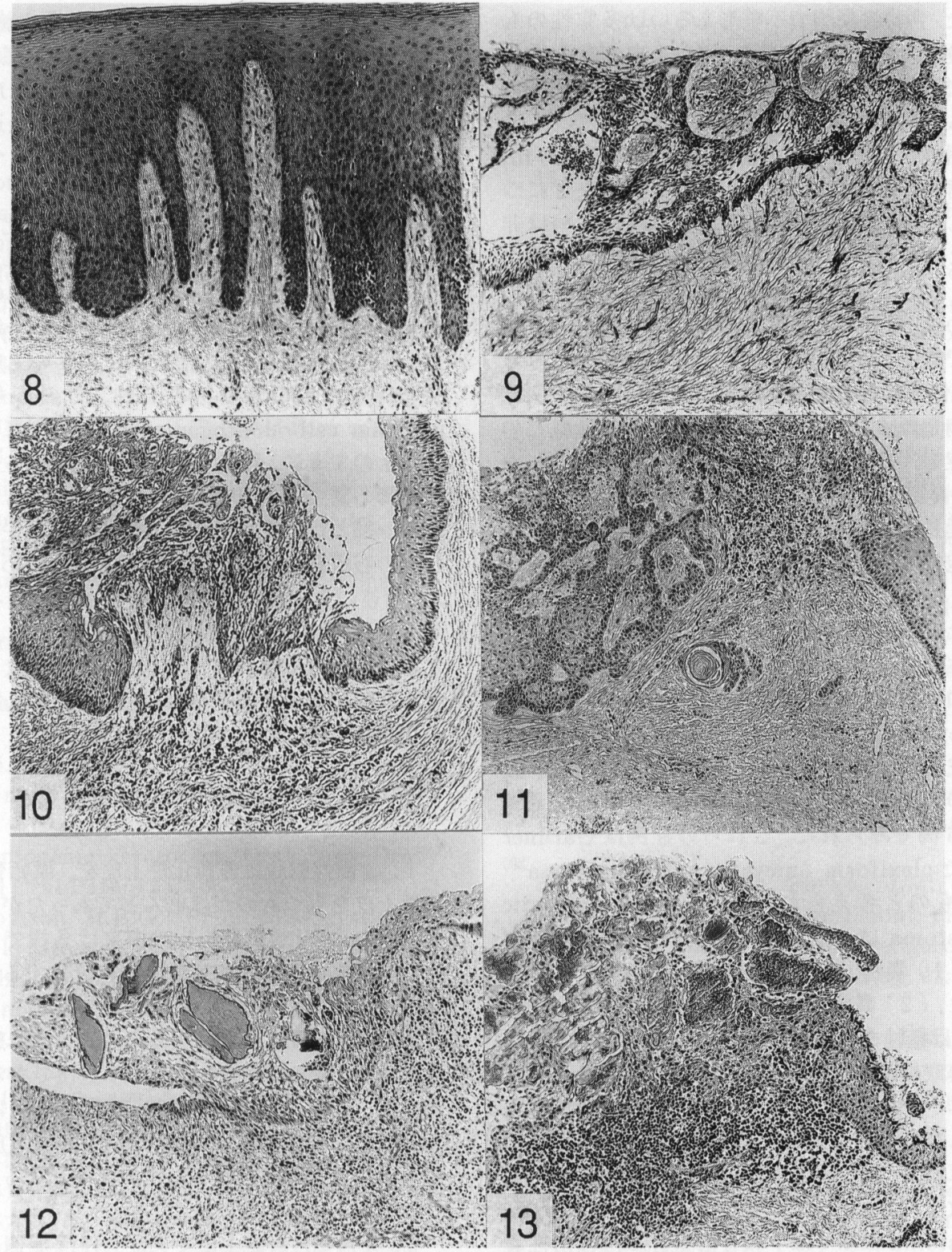

写真 8 炎症を伴わない襄胞上皮の上皮脚の延長 $(\times 86)$. 襄胞壁内への著明な上皮脚の延長がみられる。

写真 9 炎症を伴わない襄胞上皮のレース状増生像 $(\times 72)$. エナメル上皮腫様の上皮の増生がみられる.

写真 10 エナメル上皮腫様の囊胞上皮の増生像 $(\times 72)$. 輁胞腔側に増生している。

写真 11 エナメル上皮腫様の上皮の増生像 $(\times 61)$. 嚢胞壁内に増生している。

写真 12 襄胞上皮内の石灰化 $(\times 86)$. 囊胞上皮の増生と石灰化物がみられる。

写真 13 䡛胞上皮内の石灰化 $(\times 86)$. 襄胞上皮の著明な増生部に多数の石灰化物がみられる. 
が高かった. 含歯性囊胞で不整形あるいは多胞性のも

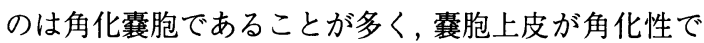
あることが不整形あるいは多胞性となる重要な因子の 一つであると思われた。

囊胞周囲の骨の膨隆や皮質骨の消失および菲薄化, 隣接歯の歯槽硬線の消失, 歯根の吸収, 失活などにつ いて検討したが, 含歯性襄胞と原始性囊胞あるいは非 角化襄胞と角化囊胞との間にはそれらの頻度には差が なかった.しかし, 輁胞周囲の X 線学的な骨硬化線の 性状については, 含歯性襄胞よりも原始性囊胞の方が より明暸であることが多かった. 全症例を通してみる と, 炎症を伴う症例では囊胞周囲の骨硬化線は不明瞭 になる傾向を認めたが, 含歯性襄胞と原始性囊胞との 間には炎症を伴う頻度には差はみられなかった。しか し, 含歯性囊胞では炎症を伴う場合に襄胞上皮の增生, 上皮脚の延長, レース状変化が高頻度に認められたが, 原始性囊胞ではそれらの上皮の変化はほとんどみられ なかった。このように, 原始性襄胞で多くみられる角 化性震胞上皮の方が炎症に対して抵抗性で, 䡛胞上皮 の変化を生じにくいことが示唆され，その結果として 震胞周囲の骨硬化線が保たれることが多いのではない かと考えられた。

䡳胞上皮を病理組織学的にさらに検索したところ， 襄胞上皮のエナメル上皮腫様増殖像が全症例の $10 \%$ にあたる 6 例でみられた。これらの症例は Gardner が報告した plexiform unicystic ameloblastoma $a^{20)}$ に類似のものと考えられる. plexiform unicystic ameloblastoma は, 1970 年にVickers と Gorlin が 提唱した（1）囊胞上皮の基底細胞の核がクロマチン に富むこと，（2）襄胞上皮の基底細胞は柵状配列を示 し，その核は極性を持ち囊胞壁側にあること，（3）襄 胞上皮の基底細胞の細胞質には空胞化がみられること， といったエナメル上皮腫の組織学的診断基準 21 をを完 全に満たしていないために, ameloblastoma の亜型 とみなされたり，単なる上皮の過形成とみなされたり， 見解の一致をみていない22, 23). plexiform unicystic ameloblastoma は多くは下顎智歯を含んだ含歯性囊 胞状とされているが, われわれの症例では 1 例のみで, 下顎小臼菌を含んだものが 2 例, 上顎智歯を含んだも のが 1 例，上顎前歯を含んだものが 1 例，下顎体部に 生じた原始性襄胞が 1 例と, 発生部位や囊胞の種類な どはさまざまであった。このような譲胞上皮の変化は, 過去に報告されているように24, 25), 放置していればエ ナメル上皮腫に変化していた可能性も十分にあると思 われたが, いずれの症例も Vickers と Gorlinによる エナメル上皮腫の組織学的診断基準を満たしていなかっ た。さらに, 従来報告された plexiform unicystic ameloblastomaの典型的な組織像と比較すると, 上 皮の変化は軽度であったため, 本研究ではこれらの診 断を含歯性あるいは原始性囊胞とした。なお，治療と
しては 5 例で摘出術を, 1 例で開空術を施行したが, いずれも経過は良好で現在まで再発をみていない。こ のことから, 震胞上皮の一部にエナメル上皮腫様の増 殖がみられる症例では, 十分な治療後の経過観察は必 要ではあるが, 通常の襄胞の治療法で差しつかえない ものと思われた。

襄胞上皮あるいは䡛胞壁の一部に石灰化を認めた症

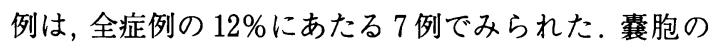
部位, 襄胞の種類, 角化の有無, 輁胞周囲の性状や変 化との明らかな関係はなかった. 興味ある症例として は, エナメル上皮腫様の上皮増生に伴い上皮内に石灰 化を伴ったものが 3 例みられ，そのうちの 2 例は granular cell odontogenic cystに類似していた.

以上のように, 輁胞上皮は炎症に伴って上皮の増生, 上皮脚の延長, レース状変化を示すとともに, 䡛胞上 皮の一部とはいえエナメル上皮腫様增殖や襄胞上皮の 一部の石灰化といった興味ある変化も認められた。ま た, 前述のように角化襄胞上皮の由来は種々のものが 考えられ, 非角化性の歯原性上皮が角化性上皮に分化 する可能性も示唆された.これらのことより，歯原性 上皮は活発な増殖能を有し, さらに潜在性分化能もも つことが示唆された.

結

語

1. 含歯性襄胞は非角化性上皮を，原始性棗胞は角 化性上皮をもつものがほとんどであったが，例外も認 められた. 角化性䡛胞上皮の由来は多様であり, 非角 化性の歯原性上皮が角化性上皮に分化する可能性も示 唆された。

2. 原始性輁胞は含歯性輁胞に比べて形態は不整形 であり，娘囊胞の存在も含めて多胞性であることが多 かった．また，含歯性襄胞で不整形あるいは多胞性の

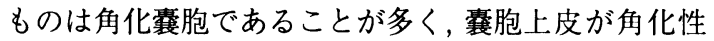
であることが不整形あるいは多胞性となる重要な因子 の一つであると示唆された。

3. 非角化性襄胞上皮で炎症を伴う症例では, 輁胞 上皮はレース状に変化し, 上皮脚も延長し, 輁胞周囲 の骨硬化線が不鮮明になる傾向があった。しかし，角 化性囊胞上皮では炎症による囊胞上皮の変化は少なく, 囊胞周囲の骨硬化線は比較的明瞭であることが多かっ た。

4. 襄胞上皮に上皮脚の延長, レース状変化, 増生 像を認め, エナメル上皮腫様の増殖像を呈した症例や,

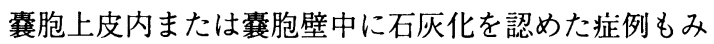
られた.これらの変化は, 襄胞の種類や襄胞上皮の角 化の有無を問わず認められた。このことより，歯原性 上皮は活発な増殖能を有し, さらに潜在性分化能も有 する可能性が示唆された。 
本論文の要旨は第 45 回日本口腔科学会総会 (平成 3 年 5 月 16 日, 京都) において発表した。

\section{引用文 献}

1) Thoma, K.H.: Oral Pathology. 3rd Ed, Mosby Co, St Louis, 1950, p914.

2) Thoma, K.H., Goldmann, H.M.: Oral Pathology. 5th Ed, Mosby Co, St Louis, 1960, p780.

3) Shafer, W.G., Hime, M.K., et al.: A Textbook of Oral Pathology. 4 th Ed, W.B. Saunders Co, Philadelphia, 1983, p258-317.

4) 石川梧朗, 秋吉正豊 : 口腔病理学 II. 永末書店, 京都, 1982, 372-386 頁.

5) Philipsen, H.P.: Om keratocyster (kolesteatomer) i kaebern. Tandlaegebladet 60 : 963-969 1956.

6) Kramer, I.R.H., Pindborg, J.J., Shear, M.: Histological Typing of Odontogenic Tumours. 2 nd Ed, Springer-Verlag, Berlin, 1992, p35-36.

7) Shear, M.: Cysts of the Oral Regions. 1 st Ed, John Wright \& Sons Ltd, Bristol, 1976, p 4 .

8) Payne, T.F.: An analysis of the clinical and histopathologic parameters of the odontogenic keratocyst. Oral Surg Oral Med Oral Pathol 33: 538-546 1972.

9) Robinson, H.B.G.: Primordial cyst versus keratocyst. Oral Surg Oral Med Oral Pathol 40: 362-369 1975.

10) Brannon, R.B.: The odontogenic keratocyst. A clinicopathologic study of 312 cases. Part I, Clinical features. Oral Surg Oral Med Oral Pathol 42: 54-72 1976.

11）堀内康夫, 他：顎骨内疾患による歯の吸収に関 する研究 第 2 報 歯原性角化裹胞および歯原 性非角化襄胞. 口科誌 27: 468-469 1978.

12）守谷友一, 他 : 最近 5 年間の顎骨襄胞に関する 臨床統計的観察一特に原始性裹胞の鑑別診断に ついて一. 日口外誌 27: 931-939 1981.

13) Altini, M., and Cohen, M.: The follicular primordial cyst (odontogenic keratocyst).
Int J oral Surg 11: 175-182 1982.

14）横林敏夫 : 非角化性原始性囊胞および類似顎骨

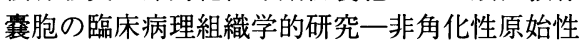
襄胞の存在意義について一. 日口外誌 29: 109011061983.

15) Stoelinga, P.J.W. and Peters, J.H.: A note on the origin of keratocysts of the jaws. Int J Oral Surg 2 : 37-44 1973.

16) Stoelinga, P.J.W.: Studies on the dental lamina as related to its role in the etiology of cysts and tumors. J Oral Pathol 5 : 65731976.

17) Killy, H.C. and Kay, L.W.: Benign Cystic Legions of the Jaws. Their Diagnosis and Treatment. 3 rd Ed, E. \& S. Livingston Ltd, Edinburgh and London, 1977, p60-93.

18）榎本昭二, 他 : 原始性豪胞 (Primordial cyst) の臨床的研究. 日口外誌 23: 121-128 1977.

19) Mclvor, J.: The radiological features of odontogenic keratocysts. Br J Oral Surg 10: 116-125 1972.

20) Gardner, D.G.: Plexiform unicystic ameloblastoma: A diagnostic problem in dentigerous cysts. Cancer 47: 1358-1363 1981.

21) Vickers, R.A. and Gorlin, R.J.: Ameloblastoma: Delineation of early histopathologic features of neoplasia. Cancer 26: 699-710 1970.

22) Generson, R.M., Porter, J.M., et al.: Mural odontogenic epithelial proliferations within the wall of a dentigerous cyst: Their significance. Oral Surg 42: 717-721 1976.

23) Solomon, M.P., Bridbord, J.W., et al.: Pseudoameloblastomatous changes in the wall of a radicular cyst. Am J Clin Pathol 61: 443-447 1974.

24) Leider, A.S., Eversole, L.R., et al.: Cystic ameloblastoma. A clinicopathologic analysis. Oral Surg Oral Med Oral Pathol 60: 624-630 1985.

25) Holmlund, A., Anneroth, G., et al.: Ameloblastomas originating from odontogenic cysts. J Oral Pathol Med 20: 318-321 1991. 